\author{
Aniela Dylus \\ Cardinal Wyszyński University in Warsaw \\ Faculty of History and Social Sciences \\ Institute of Political Science \\ e-mail: a.d@poczta.wp.pl
}

\title{
The crisis of social market economy in the context of globalisation processes*
}

\begin{abstract}
In the context of globalisation processes, the social market economy (SME) is in crisis. A reflection on the features of this model is closely related to the scientific dispute over its designation. It could be perceived as a theory, a political programme, a sort of economic order, a structure, a model or a system of economic and social development. Sometimes it is perceived as an idealistic vision or even a political utopia (Niklas Luhmann). Others (e.g.: Peter Koslowski) argue that this system has come to an end. To support this thesis, they refer to various arguments: a lack of consensus on redistribution, a demographic crisis, the depletion of solidarity resources, an intergenerational imbalance that threatens retirement systems and many others. Despite the range of these arguments, it appears that the SME still has a certain potential that could be freed. Combating difficulties associated with globalisation processes, such as the dominance of the economy over politics, 'tax starvation' of the welfare state, marginalisation of trade unions, dispersion of ownership and its detachment from responsibility, "financialisation" of economy, or dominance of 'casino capitalism', could help to heal the SME. The crisis in financial markets might be paradoxically an opportunity to return to the ethical foundations of the SME.
\end{abstract}

Keywords: social market economy, crisis, globalisation

JEL Classification: F68

\footnotetext{
* The article is an updated version of the paper published in Polish in the Annales. Ethics in Economic Life, 14(1), 33-38.
} 


\section{Introduction}

In the country where ordoliberalism was born, the debate around the successive versions of 'open system', i.e. the system of social market economy (SME), has continued since the times of Ludwig Erhard. It gained momentum in revolutionary periods, such as the unification of Germany, or during the changes in economic conditions. Recently, in the context of globalisation, doubts have arisen if this system will stand the test of time. The directions of modification of the economic and social systems, especially the interdependence between these systems, have been considered. Also, in the face of the growing importance of "environmental issues", the redefining of this system and the transition to the "eco-social market economy" have been suggested. In connection with the recent financial and economic crisis, the issue of "regulatory policy" (Ordnungspolitik $\left.{ }^{1}\right)$ is being revived once more. $^{2}$

In Poland, immediately following the systemic transformation, the first Prime Ministers of the Third Polish Republic (Tadeusz Mazowiecki, Hanna Suchocka, and Waldemar Pawlak) promised the creation of the SME, and the newly emerging political parties included it in their programmes. Moreover, pursuant to the provisions of our Constitution, the SME should form "the basis of the economic system of the Republic of Poland" (Art. 20). It seems that this Article goes even further than the "social state principle" included in the Constitution of Germany. It does not mean, however, that this clear declaration related to the political system in Poland has been consistently implemented.

Problems with implementing the principles of "Rhine capitalism" are not, however, only uniquely Polish. It seems that in the context of globalisation processes, this model of the political system, so extremely effective after World War II, is undergoing a visible crisis: in Germany and in other European countries.

It is therefore worth asking the question what the said crisis consists in. Should the end of the SME be expected in the context of globalisation? Is the idea no longer relevant partially or in its entirety? What elements of this system have not stood the test of time? If, however, the SME still retains a certain potential, one should identify the challenges that processes of globalisation generate for this system. Moreover, in view of the sometimes-encountered hypothesis of its utopian nature, it is advisable to first determine what the formal status of the designation of the term "SME" is.

\footnotetext{
${ }^{1}$ Ordnungspolitik and Ordnungsökonomik - as it seems - are the trademarks of German economic sciences. Not only the Polish language but also English lacks convincing analogues of these terms. This does not mean that the issue itself, i.e. regulatory policy and constitutional (regulatory) economics, is not the subject of analysis conducted by such eminent economists as James Buchanan or Amartya Sen. Cf. Goldschmidt, Wegner, Wohlgemuth \& Zweynert, 2009.

${ }^{2}$ The series of articles published by the opinion-forming, conservative daily "Frankfurter Allgemeine Zeitung" under the common title The Future of Capitalism presented opinions of eminent modern scholars, politicians and intellectuals, e.g.: Martin Walser.
} 


\section{The formal status of the SME}

As a result of scientific reflection of Freiburg ordoliberal school dating back to the 1930s and 1940s, the SME is a certain theoretical concept or a political and economic theory. The SME was put into practice by Ludwig Erhard (the monetary reform of June 20, 1948 is seen as its initiation) and, with the support of CDU/CSU, became Germany's long-term Christian Democrats programme, and finally - its economic and social order. Anchored in the Constitution and embedded in the legal framework of regular legislation, it has become a system. Such organising of the sphere of economic and social activity into one entirety allows us to speak of a theoretical model or the SME system functioning in reality. It is, of course, a system open to changes, modifications and adjustments - depending on changing economic conditions and forms of social life. Such a status is granted to the SME by various encyclopaedias, dictionaries and textbooks (cf. e.g.: Schlecht, 2002, pp. 646-647; Dardziński, 2004, pp. 1292-1302). In some of these reference books, its identification is weaker, for example, in the term "political and economic ideal" (Leitbild) (Schlecht, 1987, p. 568).

Undoubtedly, from the very beginning, the SME has also been a vision with a strong appeal, evoking positive associations of a successful combination of market freedom and social balance, economic rationality and social justice. As such, it has consequently mobilised people to become involved. Niklas Luhmann even identifies the SME as a "political utopia," attempting to reconcile the systemic goals of capitalism and socialism in one system. In his opinion, however, it was utopia sui generis, as it did not contain any components of criticism of political and economic reality. It was not-like other utopias - a contrasting image of the existing reality. The utopian elements of the SME are associated by Luhmann with the ambiguity of the word "social". On the one hand, since all communication, including the one taking place through the market, from the simplest buyingselling operations to sophisticated forms of mafia blackmail, has a social character, the "SME" formula is a tautology. On the other hand, the word 'social' evokes positive associations of a friendly attitude towards others. It relates to the long modern tradition of almost equalising the terms "social" (sozial) and "moral" (moralisch). Therefore, in the "SME" formula, there is an embedded suggestion about the moral good of this tautology. At the same time, the semantic ambiguity makes the SME an invisible utopia (cf. Luhmann, 1994, as cited in Bergsdorf, 2010, p. 38).

Regardless of the accuracy of these original considerations, political scientists and philosophers indicate today that in the postmodern times the demand for utopia is decreasing. The dream of utopia ended with the implosion of the communist system. Utopian ambitions have been discredited to the point that the very word "utopia" has almost disappeared from the political dictionary. In this place, a rhetorical phrase "vision" has appeared, but also this term does not hold a great appeal. Undoubtedly, the vision of united Europe, once mobilising Europeans to 
act, has lost its glitter, as has the SME vision. In the context of globalisation processes, and more recently - of the global crisis in financial markets, there has been some doubt about the regulatory power of this system (cf. Bergsdorf, 2010).

\section{The end of the SME?}

In the discourse around the SME, the opinions can be often encountered that the conditions of modern economic and social life are so far removed from the conditions in which this system originated that its principles require such fundamental modifications that it is actually hard to speak today of its further existence. For example, the well-known philosopher and economist Peter Koslowski (2006) announced 12 years ago The End of the Social Market Economy. It is worth quoting his arguments for such a radical thesis.

If it is a system based on consensus, he notes that any modifications of the system would require such a consensus. Although when the majority of those who earn less carries out fiscal exploitation of the better-earning minority-through progressive taxation, formal democratic procedures are not violated, it is difficult to speak of the universal legitimacy of the SME. The same applies to the social security system, which de facto leads to the exploitation of the minority of large families by childless families and masses of single people. In general, most redistributive projects are coerced by majority decisions.

What is disturbing is the long-growing imbalance between the rights of employees and owners. The so-called parity participation in management (paritätische Mitbestimmung), characteristic of German corporationism, violates the property right which is the foundation of the SME.

An even more powerful argument that indicates "the end of the SME" is the gradual depletion of solidarity resources. Many factors lead to the wastage of this "rare good": a demographic crisis, the individualistic spirit of the times, wrong political decisions, and finally-migrations, intensified by globalisation processes. Without solidarity, social security systems, especially pension schemes, which are the core of the SME, really break down. Solidarity is based on the expectation of reciprocity, which in turn is based on the feeling of belonging, on shared historical experiences and on the political long-term guarantee of this reciprocity. This, in turn, raises the awareness of being a community of fate-also in the economic sense - and the willingness to participate in this community. Immigrants do not have access to all this. They are unable to fulfil the conditions of participation in the social security system based on long-term national solidarity.

A proper relationship between the number of employees and retirees is a prerequisite for the functioning of the pension system. Violation of this relationship results in the disturbance of the generational order in the family. This touches upon probably the most fundamental issue: intergenerational justice. Before, all traditional societies had sanctions for reciprocity avoidance that would violate the intergenerational balance. This applies to, for example, bachelorhood, homosexual 
relationships, divorces, or abortion. The resignation of modern societies from the application of sanctions for such behaviour is an extremely risky decision from the point of view of the pension system. Equal taxation of homosexual couples and families and their equal entitlement to pensions are based on the premise that both communities equally implement intergenerational justice. However, this is a false premise. Disturbing the proportion between generations must give rise to a sense of injustice, and thus to the weakening of readiness for reciprocity.

It is hard to deny Koslowski's insightful observations. A consensus deficit in redistribution, a demographic crisis, the depletion of solidarity resources, and the disturbance of the intergenerational balance that undermines the pension system-these are social facts. Some of these issues have become more pressing as a result of intensified migration processes in the era of globalisation. While for some people changes in the social context, including changes in social customs, and economic changes connected with globalisation are so far-reaching that they practically mark the end of the SME, for others they are only a challenge to modify its principles.

\section{Challenges related to the globalisation of the economy}

Problems with the continuation - under the conditions of globalisation - of the social and economic policy in accordance with the SME principles have been growing for a long time. The sudden financial crisis of 2008 only revealed these difficulties and made them more evident. Without undertaking in-depth economic analyses here, it is worth, however, synthetically highlighting the most important of these problems.

Perhaps the most visible feature of globalisation is the deepening disproportion between the sphere of economy and politics. The dynamic economy "defies" state regulations. Transnational corporations are increasingly less dependent on the rules set by nation states. Establishing branches in various corners of the globe, they are the ones setting conditions for states to meet. Servicisation, deterritorialisation and dislocation of the global economy mean such its mobility that the state is not always able to follow. Whereas the SME system assumes an active role of the state in the economy. In addition to the long-term regulatory policy, the state's "discreet presence" in the economy is desirable to prevent crises and stimulate market processes. The attempts made to set the transnational political "framework conditions" in this situation, e.g.: under the WTO, the G20 arrangements etc. are far from successful.

Disturbing the proper relationship between the global economy and politics, and sometimes even the subordination of the "social state" to transnational enterprises, also hinders the implementation of social policy. If the state is "taxstarved" (Peter Drucker) by corporations, it will not be able to fulfil its redistributive function well in line with the SME principles. In this situation, it is difficult to 
accept debt for financing various social programmes. It means living at the expense of future generations, which is against the principles of intergenerational justice.

In accordance with its assumptions, the SME is supposed to be a "peace system" based on harmonious cooperation and dialogue between social partners. Under the conditions of globalisation, at least one of these partners is experiencing a serious crisis, i.e. trade unions. Contrary to Peter Koslowski's fears, it is their position that has been deteriorating. The already mentioned business mobility, multinationalism and multiculturalism of employees as well as the decline in the importance of industry are not conducive to the consolidation of trade union organisations. Statistical data clearly signal a decline in trade union membership, especially among employees of global companies.

Contrasting Anglo-Saxon capitalism with Rhine capitalism, Michel Albert (1994) pointed out years ago that the first is based mainly on the capital market, while the other is based on the banking system. For over the quarter-century that has passed since those analyses, turnover in global financial markets, including speculative operations, has increased many times. Therefore, for several decades the global economy has slowly become "a colossus with clay feet," which - as predicted - sooner or later must break down (cf. Kern, 1997, pp. 145-146). The gaping shears between the huge dynamics in financial markets and the much slower growth of "real economy" have been signalled with concern. This means the formation of "capitalism without owners", i.e. a system in which property is so dispersed that the once obvious coincidence of ownership and responsibility disappears altogether. Depending on the market situation, mobile capital is in constant motion. Capital flows, acquisitions and mergers take place quickly and frequently. It is no longer the socially useful, responsible, though of course selfinterest-oriented, the creation of goods and provision of services to meet human needs that determine economic success but instead the poker risk of the financial game.

The so-called financialisation of the economy ${ }^{3}$ means de facto a fundamental systemic change. "Casino capitalism" appears. This happens when the financial sector becomes independent, i.e. it ceases to perform its ancillary macro-economic function towards the real economy, consisting in converting savings into investments. Risk-based and profit-driven casino gambling is a zero-sum game. Success depends in this case on luck and misleading the other participants of the game. They are not customers or business partners that can be trusted but opponents on whom one can at most enforce compliance with the "rules of the game." It has little to do with responsible economic activity aimed at meeting people's needs. Actually, there is a complete change in the economic paradigms. Traditional capitalism is based on transactions. These, in turn, are hard to imagine without relationships based on the mutual trust of parties involved and without the adherence to the unwritten rule: pacta sunt servanda.

\footnotetext{
${ }^{3}$ An insightful analysis of this phenomenon has been conducted by Paul H. Dembiński (2011).
} 
The key category of the SME is active market participation. Therefore, innovative entrepreneurs basing their success on traditional bourgeois virtues, without avoiding responsibility towards stakeholders, could count on support from the economic policy. Whereas globalised "casino capitalism" requires above all smooth navigation of financial markets. This type of capitalism rewards not so much staid entrepreneurs as speculative behaviours, which are sometimes called the apostasy of entrepreneurship (cf. Sadowski, 2008, p. 6).

Without trust-based transactions and entrepreneurship, in the long run, probably no capitalism, including Rhine capitalism, will survive. Perhaps the recent crisis that has exposed this banal truth, paradoxically, is a chance to return to the roots, i.e. to the ethical foundations characteristic of the SME. The verification of this assumption through the exploration of the question concerning the relevance of the SME in the new socio-economic context requires, however, a separate analysis.

\section{References}

Albert, M. (1994). Kapitalizm kontra kapitalizm. Kraków: Signum.

Bergsdorf, W. (2010). Über den abnehmenden Utopiebedarf des Postmoderne. Die Neue Ordnung, H. 1, 37-47.

Dardziński, P. (2004). Społeczna gospodarka rynkowa. In B. Szlachta (Ed.), Stownik spoteczny. Kraków: WAM.

Dembiński, P. H. (2011). Finanse po zawale. Od euforii finansowej do gospodarczego tadu. Warszawa: Studio Emka.

Dichtl, E., \& Issing, O. (Eds.). (1987). Vahlens Großes Wirtschafts Lexikon (Vol. 2). München: C.H. Beck, F. Vahlen.

Dylus, A. (2011). Kryzys społecznej gospodarki rynkowej w kontekście procesów globalizacji. Annales. Ethics in Economic Life, 14(1), 33-38.

Goldschmidt, N., Wegner, G., Wohlgemuth, M., \& Zweynert, J. (2009, June 19). Was ist und was kann Ordnungsökonomik? Frankfurter Allgemeine Zeitung, 139.

Kern, B. (1997). Koloß auf tönernen Füßen. Concilium, 2.

Koslowski, P. (2006, Novermber 11). Das Ende der Sozialen Marktwirtschaft. Frankfurter Allgemeine Zeitung, 263.

Luhmann, N. (1994). Kapitalismus und Utopie. Merkur, 3, 189-198.

Sadowski, A. (2008, October 31-November 2). Upadek fałszywych bogów. Rzeczpospolita [Supplement: "Lista 2000. Polskie przedsiębiorstwa"].

Schlecht, O. (2002). Soziale Marktwirtschaft. In W. Becker, G. Buchstab, A. DoeringManteuffel, \& R. Morsey, Lexikon der Christlichen Demokratie. PaderbornMünchen-Wien-Zürich: Ferdinand Schöning. 